\title{
Teori Kewirausahaan Limpahan Pengetahuan: Inovasi dari Mobilisasi Informasi
}

\author{
Agung Purnomo \\ Program Studi Kewirausahaan \\ Universitas Bina Nusantara \\ agung.purnomo@binus.ac.id
}

Riset kewirausahaan di Indonesia kian tumbuh dan berkembang (Purnomo et al., 2019). Entrepreneurship atau kewirausahaan adalah proses kegiatan seorang wirausahawan sebagai orang memulai dan mengelola bisnis dengan mengeksploitasi ide-ide bisnis menjadi peluang yang menguntungkan atau memberi manfaat (Purnomo et al., 2020). Untuk memahami dan mengembangkan pengetahuan kewirausahaan, para ilmuwan melakukan riset dan mengembangkan beberapa teori kewirausahaan.

Salah satu teori kewirausahaan yang berkembang adalah teori kewirausahaan limpahan pengetahuan (the knowledge spillover theory of entrepreneurship). Apa yang dimaksud dengan teori kewirausahaan limpahan pengetahuan tentang?. Teori kewirausahaan limpahan pengetahuan adalah adanya inovasi produktif berasal dari perusahaan lama berupa perusahaan mapan dan pendatang baru yaitu pengusaha dan organisasinya (Acs et al., 2009; Audretsch \& Lehmann, 2005).

Pengetahuan secara inheren bocor, dan bergerak melalui jaringan dan melalui mobilitas pemangku kepentingan. Ini mungkin asumsi yang memudahkan karena banyak organisasi merasa sangat sulit untuk menyimpan rahasia. Pelapor, misalnya, menunjukkan batas kerahasiaan saat mereka membocorkan informasi yang memberatkan majikan mereka. Limpahan pengetahuan dianggap sebagai sumber utama pertumbuhan dan pembangunan ekonomi karena merupakan sumber peluang wirausaha. Kewirausahaan adalah tentang membuat kombinasi baru, tetapi sumber bahan mentah untuk kombinasi tersebut harus datang dari suatu tempat (Laplume $\&$ Yeganegi, 2017).

Pengetahuan dapat bocor dari organisasi dalam bentuk spin out yaitu karyawan menjadi wirausahawan, atau ketika karyawan pergi bekerja untuk organisasi lain termasuk pesaing langsung. Pengetahuan tersebut juga dapat mengalir melalui transfer pengetahuan eksplisit, misalnya, publikasi dan paten. Ketika incumbent efisien dalam mengeksploitasi pengetahuan yang mereka ciptakan, maka peluang bagi pendatang baru akan lebih sedikit. Namun, penggunaan pengetahuan yang tidak efisien oleh petahana menyebabkannya bocor keluar dari organisasi tersebut sehingga memungkinkan pendatang baru untuk memanfaatkannya. Misalnya, pemegang saham lama sering berinvestasi dalam inovasi yang tidak mereka manfaatkan kemudian 
karena mereka mungkin menganggap inovasi tersebut bertentangan dengan kepentingan perusahaan mereka (Agarwal et al., 2010).

Inovasi dapat mengkanibal penjualan atau mengurangi nilai aset dan sumber daya perusahaan, atau mengancam margin. Akibatnya, karyawan yang ingin mengejar inovasi yang tidak didukung oleh perusahaan induk dapat memutuskan untuk keluar untuk bergabung dengan perusahaan lain atau memulai usaha baru. Banyak tindakan dan kebijakan organisasi dapat dipandang sebagai upaya menekan limpahan pengetahuan. Misalnya, skema kompensasi, kontrak yang tidak bersaing, dan hak kekayaan intelektual seringkali menyulitkan pengusaha untuk memanfaatkan limpahan pengetahuan dalam usaha baru mereka (Laplume \& Yeganegi, 2017).

\section{References}

Acs, Z. J., Braunerhjelm, P., Audretsch, D. B., \& Carlsson, B. (2009). The knowledge spillover theory of entrepreneurship. Small Business Economics, 32(1), 15-30. https://doi.org/10.1007/s11187-008-9157-3

Agarwal, R., Audretsch, D., \& Sarkar, M. (2010). Knowledge spillovers and strategic entrepreneurship. Strategic Entrepreneurship Journal, 4(4), 271-283. https://doi.org/10.1002/sej.96

Audretsch, D. B., \& Lehmann, E. E. (2005). Does the Knowledge Spillover Theory of Entrepreneurship hold for regions? Research Policy, 34(8), 1191-1202. https://doi.org/10.1016/j.respol.2005.03.012

Laplume, A., \& Yeganegi, S. (2017). Knowledge spillover theory of entrepreneurship. Entrepreneurship Theories.

https://entrepreneurshiptheories.blogspot.com/2017/08/knowledge-spillovertheory.html

Purnomo, A., Sudirman, A., Hasibuan, A., Sudarso, A., Sahir, S. H., Salmiah, Mastuti, R., Chamidah, D., Koryati, T., \& Simarmata, J. (2020). Dasar-Dasar Kewirausahaan: untuk Perguruan Tinggi dan Dunia Bisnis. Yayasan Kita Menulis.

https://kitamenulis.id/2020/04/06/dasar-dasar-kewirausahaan-untuk-perguruantingi-dan-dunia-bisnis/

Purnomo, A., Usman, I., \& Asitah, N. (2019). Penelitian Kewirausahaan di Indonesia : Pemetaan Publikasi dalam Perspektif Scientometrik (1972-2019). AdBispreneur, 4(3), 207. https://doi.org/10.24198/adbispreneur.v4i3.25021 